Edith Cowan University

Research Online

ECU Publications Post 2013

$1-1-2014$

Soil seed banks of fringing salt lake vegetation in arid Western

Australia - density, composition and implications for postmine restoration using topsoil

\author{
Eddie J. van Etten \\ Edith Cowan University \\ Brett Neasham \\ Sarah Dalgleish \\ Edith Cowan University
}

Follow this and additional works at: https://ro.ecu.edu.au/ecuworkspost2013

Part of the Ecology and Evolutionary Biology Commons, and the Environmental Sciences Commons

10.1111/emr.12119

This is the peer reviewed version of the following article: [van Etten E.J., Neasham B., \& Dalgleish S. (2014). Soil seed banks of fringing salt lake vegetation in arid Western Australia - density, composition and implications for postmine restoration using topsoil. Ecological Management and Restoration, 15(3), 239-242], which has been published in final form here. This article may be used for non-commercial purposes in accordance with Wiley Terms and Conditions for Self-Archiving.

This Journal Article is posted at Research Online.

https://ro.ecu.edu.au/ecuworkspost2013/320 


\title{
Soil seed banks of fringing salt lake vegetation in arid Western Australia - density, composition and implications for post-mine restoration using topsoil
}

\author{
Eddie J.B van Etten ${ }^{1}$, Brett Neasham ${ }^{2} \&$ Sarah Dalgleish $^{1}$ \\ ${ }^{1}$ Centre for Ecosystem Management, Edith Cowan University, 270 Joondalup Drive, Joondalup 6027 \\ Australia, e.van_etten@ecu.edu.au; ${ }^{2}$ Niche Environmental Services, PO Box 3228, Midland, WA \\ 6056.
}

\section{Summary}

Although studies of seed banks in arid ecosystems are commonplace, they are lacking for the large arid zone of Western Australia. Across the six major plant communities fringing a large salt lake within this zone, topsoil (0-5 cm depth) was collected from 12-36 sites per community. Samples were dried, spread out on a bed of vermiculite in seedling trays and placed in a well-watered glasshouse to determine the readily germinable component of the soil seed bank. Subsamples of topsoil were treated with smoke water, hot water or flooding to help determine seed bank of species with dormancy mechanisms. As with other studies of arid seed banks, large numbers of grasses and forbs emerged from the topsoil, with relatively small numbers of woody perennial species and hummock grasses (Triodia spp.) present, even in communities where such species were dominant. There were however a few exceptions where a reasonable density of dominant trees/shrub seed was present in topsoil. Soil treatment generally had limited effect on composition and density of emergent seedlings. Although floristic similarity between soil seed banks and corresponding aboveground vegetation was modest, there were clear differences in soil seed bank composition between communities. The implications of results for using topsoils to restore landforms of the study area after mining or other disturbance are discussed.

\section{$\underline{\text { Introduction }}$}

Studies of soil seed banks have improved our understanding of ecosystem dynamics and the effects of disturbance on ecosystem properties (Leck et al. 1989; Kinloch \& Friedel 2005; Tessema et al. 2012). Soil seed banks are likely to be particularly important in arid ecosystems given high rainfall variability and strongly developed seed dormancy mechanisms (Kemp 1989). They have been studied in many drylands of the world (Kemp 1989; Tessema et al. 2012), but not so for the large arid zone of Western Australia which is dominated by Acacia shrublands/woodlands and Triodia hummock grasslands.

Harvesting topsoil and spreading it over recreated landforms has become a widely used and generally successful technique for rehabilitating mined sites in temperate and tropical environments (Leck et al. 1989; Cooke \& Johnson 2002; van Etten et al. 2012), but is largely unproven in arid and semiarid zones. Studies of soil seed banks before mining are valuable because they inform us about which species are likely to emerge from topsoil and which species may be absent or not readily returned to sites where topsoil is applied, as well as where species occur in topsoil across the landscape. 
Salt lakes (playas) are common in arid lands; their margins and surrounding dunes are characterised by steep topography-hydrology-salinity gradients which usually result in distinct zonation of the fringing vegetation (Ungar 1991; Van Etten \& Vellekoop 2009). Their steep gradients and complex environmental patterns mean they typically harbour numerous vegetation types and large numbers of species within relatively small areas. More mining of salt lake margins is occurring (e.g. for gypsum, calcrete or underlying ore bodies), the rehabilitation of which presents many challenges, including how to recreate the complexity in physical and biotic features post mining. A central question is whether or not it is worth separating topsoil from the many communities to help recreate spatial patterns of vegetation types following mining?

The objectives of this study were to: 1) determine and compare the density, diversity and composition of the soil seed banks for each of the major plant communities fringing a large salt lake in the arid Murchison region of Western Australia; 2) compare the seed bank of each community with their corresponding above-ground vegetation; and 3) gauge the effect of soil treatments designed to improve germination.

\section{$\underline{\text { Methods }}$}

The study was conducted in the fringing vegetation complexes of Lake Way, a large salt lake located within the Lake Way pastoral lease approximately 20-30 km south-east of the town of Wiluna in the Murchison Bioregion, Western Australia. The area is arid with a mean annual rainfall of $258 \mathrm{~mm}$, most of which falls in summer and autumn. Inter-annual rainfall variability is high (Variability Index $=1.34$ ), mainly because significant summer rainfall is linked to the irregular passage of ex-cyclones and monsoons across the north-west of Australia. Temperatures are typically hot in summer (average maximum of $38{ }^{\circ} \mathrm{C}$ in February) to mild in winter (average maximum of $20{ }^{\circ} \mathrm{C}$ in July). The salt lake bed is flat and largely devoid of vegetation, whereas the margins of the lake and fringing dunes and plains have a number of distinct plant communities. The lake bed and margins were last inundated in 2006 (4 years before topsoil sampling).

We collected topsoil (0-5 cm depth; $0.04 \mathrm{~m}^{2}$ surface area) from at least 12 (and up to 36) randomly selected sites in each of the major plant communities surrounding the salt lake bed. Each site was separated from other sites by at least $100 \mathrm{~m}$ and was in a different patch of the community where possible. The six major plant communities sampled, in order of general distance from lake bed, were: 1) saltmarsh on margins of salt lake dominated by Tecticornia spp.; 2) halophytes (Frankenia, Tecticornia and Maireana spp.) over sparse hummock grass (Triodia spp.) and bunch grasses (Eragrostis spp.) on claypans; 3) fringing Melaleuca xerophila low woodland/forest; 4) Acacia spp. - Eucalyptus striaticalyx - Casuarina pauper low open woodland on calcrete platforms; 5) Callitris columellaris woodland over hummock grass on sandplain; 6) A. ayersiana - A. aneura - A. burkittii shrubland/woodland over hummock grass on fringing dunes and plains.

The single topsoil sample collected from each site was bagged, transported to Perth, dried and thoroughly mixed, and then split into four similar-sized subsamples, with a small amount of soil (approximately $50 \mathrm{~g}$ ) kept aside for sieving to detect larger seed and fruit. Each of the four subsamples was then spread out on a bed of vermiculite in a seedling tray and placed in a well- 
watered glasshouse (using mains water applied daily for 5 minutes in summer-autumn months, and 3 minutes in winter-spring). One subsample was not treated to determine the readily germinable component of the soil seed store (control). The other subsamples were given an initial treatment with either smoke water (Regen 2000 Smokemaster® at 1:10 dilution, poured onto surface of subsample until fully saturated), boiling water (poured onto subsamples from kettle until fully saturated), or two weeks of flooding to encourage germination of seed with dormancy mechanisms.

Seedlings emerging from seedling trays were counted monthly and grown further to identify to lowest taxonomic rank possible. The trial ran for 11 months (January to November). Glasshouse temperatures were partially controlled by heating and cooling systems and generally fluctuated, based on hourly temperature recordings using a datalogger, between $30-36^{\circ} \mathrm{C}$ during the day and 18 $25^{\circ} \mathrm{C}$ at night (which broadly corresponds to the range of daily temperatures at the study area in spring and autumn, but avoids the more extreme temperatures likely in winter and summer months). Differences in mean number of seedlings and species emerging per tray were compared between communities and treatments using generalised linear models (assuming Poisson distribution for species richness, and negative binomial distribution for seedling abundances); differences in species composition were determined using Analysis of Similarity (ANOSIM). Seed density (per $\mathrm{m}^{2}$ ) of each site was calculated from the total number of emerging seedlings from all four subsamples and the number of seed detected by sieving (scaled up to account for the proportion of soil removed for sieving by weight). Seed density was then compared between communities using ANOVA (as density approximated normal distribution). Floristic survey data collected over a number of years by the authors (both 'wet' and 'dry' years) was used to compare above- to below-ground species composition for each community using the Sorensen index.

\section{$\underline{\text { Results }}$}

In total, 2291 seedlings belonging to 72 different species emerged from topsoil over the 11 month germination trial (Table 1; Appendix 1). Sieving yielded comparatively few seeds (45) belonging to nine different species, with at least three of these species not emerging in the germination trial, although most of these seeds could not be identified to species level. There was approximately the same number of annual and perennial seedlings emerging from topsoil, with $38 \%$ of species being perennial (Table 1). However, many perennial species were herbaceous (or semi-woody) and relatively short lived; few tree and woody shrub seedlings emerged (Table 1). In terms of seedling abundances, the most common group were grasses or grass-like plants, and then chenopods and daisies (Appendix 1). Both perennial and annual grasses were found, and these were highly abundant in some soil samples. Only one weed species was found (Table 1).

The average abundance, richness and composition of emergent seedlings per site differed between communities (respective test statistics were: Wald $\chi^{2}=52.5$, Wald $\chi^{2}=90.6$, Global $\mathrm{R}=0.25$; all $\mathrm{p}<0.001$ ), with those on raised sandplains and dunes (Callitris and Acacia woodland over hummock grassland) further back from the lake having fewer species and seedlings per site than fringing saltmarsh, calcrete and claypan communities closer to the lake bed. Seed density varied widely with a similar pattern of differences between communities (Table 1). 
No differences in mean seedling abundance or species richness were found between soil treatments (Wald $\chi^{2}=3.5$ and $3.2, p=0.32$ and 0.35 , respectively). The species composition of seedlings was marginally different between soil treatments (Global $\mathrm{R}=0.025, \mathrm{p}=0.021$ ), due mainly to a very small number of seedlings $(<5)$ of hard-seeded species emerging from some heat-treated trays, such as Acacia spp., Triodia melvillei and Alyogyne pinoniana, and a greater number of Tecticornia in flooded trays.

Overall, $47 \%$ of species found in topsoil have been previously recorded in surveys of the aboveground vegetation of Lake Way, with nine species (13\%) not previously recorded (Table 1). This leaves some 29 species from topsoil with an uncertain match, either because they could not be positively identified to species rank, or because there were doubts associated with above-ground species identification. The similarity between below- and above-ground species composition varied considerably across the seven major communities (22-48\%; Table 1). For communities fringing the salt lakes, many of the dominant species were recorded in low to moderate numbers in the soil seed bank. For instance, Melaleuca xerophila dominated the vegetation of fringing woodlands in depressions, and this species emerged from most soil samples collected from this community (average of 9 seed $\mathrm{m}^{-2}$ ). Samphire shrubs (Tecticornia spp.) dominated the vegetation fringing the salt lake and were found consistently in topsoil samples from this community, albeit at reasonably low density ( $14 \mathrm{~m}^{-2}$ across all Tecticornia spp.). Dominant/common species of the sand dunes and raised plains, such as Acacia, Eremophila, Grevillea and Triodia spp., were rarely found in the soil seed bank.

\section{$\underline{\text { Discussion }}$}

Mean seed density in topsoil of fringing vegetation at Lake Way was $\sim 480 \mathrm{~m}^{-2}$ and, despite differing substantially across plant communities $\left(50-1000 \mathrm{~m}^{-2}\right)$, was generally similar to that found by Wright \& Clarke (2009) for hummock grasslands in central Australia, but was lower than found in other studies of arid Australian seed banks (Page 2009; Graham et al. 2004), and far lower than deserts in the USA, which number in several thousand seed $\mathrm{m}^{-2}$ (Kemp 1989). Further, the soil seed bank at Lake Way was found to be dominated by annual and perennial tussock grasses, forbs and short-lived shrubs, with relatively little seed of woody perennial species and hummock grasses present, even in communities where such species were dominant. There were a few exceptions where a reasonable density of dominant trees/shrub seed was present in topsoil (e.g. Tecticornia shrubs in fringing saltmarsh). Floristic similarity of seed bank with above-ground vegetation was low to moderate. Results suggests a transient seed bank for most of the perennial woody species of the study area as reported for other studies from arid and semi-arid lands; the seed store of such species tends to fluctuate dramatically in response to rainfall and disturbance patterns over time (Kemp 1989; Kinloch \& Friedel 2005; Page 2009; Wright \& Clarke 2009; Tessima et al 2011) and can be affected by high rates of seed predation by ants, birds and rodents (Morton 1985). Alternatively, seed of many perennial species could remain undetected in topsoil due to shortcomings in technique. We used two proven techniques to measure seed bank, as recommended for arid ecosystems by Wright \& Clarke (2009), although the limited volume of sieved soil (due to availability) meant it was possible we missed seed of species with sparse and/or spatially variable seed banks. 
Soil treatment generally had limited effect on composition and density of emergent seedlings. Heat and smoke treatments were designed to stimulate germination of seed which may respond to fire, although it is possible that these treatments did not fully mimic fire effects given boiling water would be cooled by soil when applied, and the smoke effect may be diluted by daily watering. The lack of a heat/smoke response in some communities may be explained by the absence of fire in these areas (e.g. saltmarsh and claypan vegetation). The heat treatment effect on species composition in other communities was subtle and mainly attributable to germination of a small number of hard-seeded species which are known to respond to heat of fire (eg Acacia spp., Malvaceae). Page (2009) found different species composition in the soil seed bank following various fire-simulating treatments for semi-arid mulga woodland in Queensland. Flooding treatment was designed to stimulate germination of seed with persistent growth-retarding hormones in seed tissue or embryo (a common dormancy strategy in drylands; Kemp 1989). A higher rate of Tecticornia emergence from flooded trays reflects the role of infrequent flooding events for the recruitment of these species at margins of salt lakes (van Etten \& Vellekoop 2009).

Despite the relatively low seed density and diversity recorded for the soil seed bank, topsoil is still likely to be valuable for restoration purposes, especially as topsoil applied to post-mine landforms can have other benefits in addition to seed supply, such as providing valuable soil microbes and a suitable media for germination and plant growth (Cooke \& Johnstone 2002; van Etten et al. 2012). However, at least some degree of direct seeding will be necessary for restoration of key dominants and overall diversity. An improved understanding of the germination requirements of such species will be required to ensure their adequate establishment in rehabilitated mine pits. Notwithstanding the need for at least some direct seeding, the compositional differences found in soil seed banks across the plant communities suggest segregating topsoil from the different communities may be worthwhile, although the benefits of this practice will largely depend on the degree to which topohydrological conditions of the original communities can be recreated following mining (van Etten et al. 2012). The practice of segregating topsoil of several different communities however presents many logistic and financial challenges.

\section{Acknowledgements}

We thank ECU for providing equipment and glasshouse facilities, and Toro Energy for providing funds to support the research. Two anonymous reviewers are thanked for their input and useful suggestions

\section{REFERENCES}

Cooke J. A. and Johnson M. S. (2002) Ecological restoration of land with particular reference to the mining of metals and industrial minerals: a review of theory and practice. Environmental Reviews 10, 41-71. 
Graham R. A., Florentine S. K., Fox J. E. D. and Luong T. M. (2004) The germinable soil seedbank of Eucalyptus victrix grassy woodlands at Roy Hill station, Pilbara district, Western Australia. The Rangeland Journal 26, 17-33.

Kemp, P. R. (1989). Seed banks and vegetation processes in deserts. In: Ecology of Soil Seed Banks, (eds M. A Leck, T. V Parker and R. L. Simpson), pp. 257-282. Academic Press Inc.

Kinloch J. E. and Friedel M. H. (2005) Soil seed reserves in arid grazing lands of central Australia. Part 1: Seed bank and vegetation dynamics. Journal of Arid Environments 60, 133-161.

Leck M. A., Parker T. V. and Simpson, R. L. (eds) (1989) Ecology of soil seed banks. Academic Press Inc.

Morton S. R. (1985) Granivory in arid regions: comparison of Australia with North and South America. Ecology 66,1859-1866.

Page M. J. (2009) Using heat and smoke treatments to simulate the effects of fire on soil seed banks in four Australian vegetation communities. Proceedings of the Royal Society of Queensland 115, 1-9.

Tessema Z. K., de Boer W. F., Baars R. M. T. and Prins H. H. T. (2012) Influence of grazing on soil seed banks determines the restoration potential of aboveground vegetation in a semi-arid savanna of Ethiopia. Biotropica 44, 211-219.

Ungar I.R. (1991) Ecophysiology of vascular halophytes. CRC Press, Boca Raton.

van Etten E. J. B. and Vellekoop S. J. (2009) Response of fringing vegetation to flooding and discharge of hypersaline water at Lake Austin, Western Australia. Hydrobiologia 626, 67-77.

van Etten E. J. B., McCullough C. D. and Lund M. A. (2012) Importance of topography and topsoil selection and storage in successfully rehabilitating post-closure sand mines featuring pit lakes. Mining Technology (Trans. IMM A) 121, 139-150.

Wright B. R. and Clarke P. J. (2009) Fire, aridity and seed banks. What does seed bank composition reveal about community processes in fire-prone desert? Journal of Vegetation Science 20, 663-674. 
Table 1. Total number (and percentage) of emergent species and seedlings, mean seedling density (per $m^{2}$ of ground; \pm standard error for communities) and Sorensen Similarity Index for the different life forms, growth forms and community types. Differences in mean seedling density between communities are shown, as determined by GamesHowell post-hoc test, with communities sharing the same letter not significantly different at $p<0.05$ (ANOVA $F=11.7, d f$ $=5, p<0.001$ ). Also included are the number of species emerging from topsoil that were (or were not) found during above-ground vegetation surveys, as well the number of seedlings found in each of these groups. Sorensen Index calculated by $(100 * 2 a) /(b+c)$ where $a=$ number of species common to above and below ground, $b=$ number of species found below ground and $c=$ number of species found in above-ground surveys of the six plant communities.

\begin{tabular}{|c|c|c|c|c|c|}
\hline $\begin{array}{l}\text { PLANT } \\
\text { GROUP }\end{array}$ & TYPE & $\begin{array}{l}\text { No. of } \\
\text { SPECIES }\end{array}$ & $\begin{array}{c}\text { No. of } \\
\text { SEEDLINGS }\end{array}$ & $\begin{array}{c}\text { MEAN } \\
\text { SEEDLING } \\
\text { DENSITY } \\
\mathbf{m}^{-2}\end{array}$ & $\begin{array}{l}\text { SORENSEN } \\
\text { INDEX }\end{array}$ \\
\hline \multirow[t]{3}{*}{ Life Form } & Perennial & $27(38 \%)$ & $1086(47 \%)$ & 225 & $46 \%$ \\
\hline & Ephemeral/Annual*@ & 39 (54\%) & $1194(52 \%)$ & 250 & $57 \%$ \\
\hline & Unknown Life Form & $6(8 \%)$ & $11(0.5 \%)$ & 2.3 & - \\
\hline Growth & Tree & $2(3 \%)$ & $54(2 \%)$ & 11 & $22 \%$ \\
\hline \multirow[t]{4}{*}{ Form } & Shrub \& sub-shrub & $17(24 \%)$ & $473(21 \%)$ & 91 & $31 \%$ \\
\hline & Forb ${ }^{@}$ & $34(47 \%)$ & $642(28 \%)$ & 141 & $52 \%$ \\
\hline & Grass \& Grass-like & $16(22 \%)$ & $1119(49 \%)$ & 232 & $69 \%$ \\
\hline & Unknown Growth Form & $3(4 \%)$ & $3(0.1 \%)$ & 0.6 & - \\
\hline Above & Found in Vegetation Surveys ${ }^{@}$ & $34(47 \%)$ & $1674(73 \%)$ & 349 & - \\
\hline \multirow[t]{2}{*}{ Ground } & Not Found in Vegetation Surveys & $9(13 \%)$ & $296(13 \%)$ & 62 & - \\
\hline & Unknown/uncertain & $29(40 \%)$ & $321(14 \%)$ & 69 & - \\
\hline Plant & 1.Saltmarsh with samphires $(n=24)$ & $31(43 \%)$ & $959(42 \%)$ & $999 \pm 158^{d}$ & $31 \%$ \\
\hline \multirow[t]{5}{*}{ Community } & 2. Halophytes on claypan $(n=12)$ & $25(35 \%)$ & $344(15 \%)$ & $717 \pm 159^{d c}$ & $48 \%$ \\
\hline & 3.Melaleuca fringing woodland ${ }^{@}(n=24)$ & $40(56 \%)$ & $566(25 \%)$ & $589 \pm 114^{d c}$ & $30 \%$ \\
\hline & 4.Calcrete platform woodland $(n=12)$ & $25(35 \%)$ & $140(6 \%)$ & $292 \pm 44^{\mathrm{bc}}$ & $30 \%$ \\
\hline & 5.Callitris woodland on sandplain $(n=12)$ & $14(19 \%)$ & $25(1 \%)$ & $52 \pm 15^{a}$ & $33 \%$ \\
\hline & 6.Acacia shrubland on dunes $(n=36)$ & $44(61 \%)$ & $257(11 \%)$ & $177 \pm 35^{b}$ & $22 \%$ \\
\hline ALL SPECIES & & 72 & 2291 & $477 \pm 53$ & $42 \%$ \\
\hline
\end{tabular}

*includes 'short-lived perennial species' which may persist for 1-2 years if moist soil conditions prevail.

@ includes one weed species ( 2 seedlings of Acetosa vesicaria, ruby dock) 
Appendix 1. Identification and characteristics of species emerging from topsoil samples. Nomenclature follows Florabase v2.8 (https://florabase.dpaw.wa.gov.au/ ) as of March 2014. * = exotic species

Published as a supplementary table to van Etten et al. (2014) Soil seed banks of fringing salt lake vegetation in arid Western Australia - density, composition and implications for post-mine restoration using topsoil. Ecological Management \& Restoration, volume 15.

\begin{tabular}{|c|c|c|c|c|c|c|c|}
\hline Family & Genus & Species & $\begin{array}{c}\text { Collect } \\
\text { in Veg } \\
\text { Surveys } \\
? \\
\end{array}$ & $\begin{array}{l}\text { Life } \\
\text { Form }\end{array}$ & $\begin{array}{c}\text { Annual } \\
\text { or } \\
\text { Perennial }\end{array}$ & $\begin{array}{l}\text { TOTAL } \\
\text { SITES }\end{array}$ & $\begin{array}{c}\text { TOTAL } \\
\text { Abundance }\end{array}$ \\
\hline$?$ & $?$ & Unknown sp. 1 & $?$ & Forb & A & 6 & 8 \\
\hline$?$ & ? & Unknown sp. 2 & ? & $?$ & $?$ & 1 & 1 \\
\hline$?$ & ? & Unknown sp. 3 & ? & Forb & A & 5 & 8 \\
\hline$?$ & ? & Unknown sp. 4 & $?$ & Forb & $A$ & 4 & 6 \\
\hline$?$ & ? & Unknown sp. 5 & $?$ & Forb & $A$ & 1 & 1 \\
\hline$?$ & $?$ & Unknown sp. 6 & $?$ & Forb & $A$ & 1 & 1 \\
\hline$?$ & $?$ & Unknown sp. 7 & $?$ & $?$ & $?$ & 1 & 1 \\
\hline$?$ & $?$ & Unknown sp. 8 & $?$ & $?$ & $?$ & 1 & 1 \\
\hline Aizoaceae & $?$ & Unknown Aizoaceae & $?$ & Forb & $A$ & 1 & 1 \\
\hline Aizoaceae & Disphyma & crassifolium & yes & Forb & $P$ & 6 & 6 \\
\hline Aizoaceae & Trianthema & triquetra & yes & Forb & A & 10 & 43 \\
\hline Amaranthaceae & Alternanthera & nodiflora & yes & Forb & $A$ & 4 & 4 \\
\hline Amaranthaceae & Ptilotus & obovatus & yes & Shrub & $\mathrm{P}$ & 2 & 2 \\
\hline Amaranthaceae & Ptilotus & polystachyus & yes & Forb & $A$ & 1 & 1 \\
\hline Asteraceae & $?$ & Unknown Daisy 1 & $?$ & Forb & $A$ & 4 & 10 \\
\hline Asteraceae & $?$ & Unknown Daisy 2 & $?$ & Forb & A & 1 & 1 \\
\hline Asteraceae & Angianthus & $\mathrm{sp}$ & $?$ & Forb & $A$ & 11 & 150 \\
\hline Asteraceae & Gnephosis & brevifolia & no & Forb & $A$ & 3 & 7 \\
\hline Centrolepidaceae & Centrolepis & sp. & $?$ & Forb & $A$ & 19 & 27 \\
\hline Chenopodiaceae & Dissocarpus & paradoxus & yes & Forb & $A$ & 1 & 2 \\
\hline Chenopodiaceae & Dysphania & kalpari & yes & Forb & A & 16 & 80 \\
\hline Chenopodiaceae & Dysphania & glomulifera & yes & Forb & $A$ & 9 & 11 \\
\hline Chenopodiaceae & Dysphania & melanocarpum & yes & Forb & $A$ & 16 & 73 \\
\hline Chenopodiaceae & Dysphania & rhadinostachya & yes & Forb & $A$ & 2 & 14 \\
\hline Chenopodiaceae & Enchylaena & tomentosa & yes & Shrub & $\mathrm{P}$ & 23 & 267 \\
\hline Chenopodiaceae & Maireana & villosa & yes & Shrub & $P$ & 6 & 11 \\
\hline Chenopodiaceae & Maireana & sp. & $?$ & Shrub & $\mathrm{P}$ & 10 & 26 \\
\hline Chenopodiaceae & Salsola & australis & yes & Forb & $A$ & 1 & 1 \\
\hline Chenopodiaceae & Sclerolaena & sp. 1 & $?$ & Shrub & $\mathrm{P}$ & 11 & 22 \\
\hline Chenopodiaceae & Sclerolaena & sp. 2 & $?$ & Shrub & $\mathrm{P}$ & 4 & 8 \\
\hline Chenopodiaceae & Tecticornia & auriculata & yes & Shrub & $P$ & 9 & 36 \\
\hline Chenopodiaceae & Tecticornia & indica & yes & Shrub & $P$ & 8 & 58 \\
\hline Chenopodiaceae & Tecticornia & tenuis & yes & Shrub & $P$ & 2 & 3 \\
\hline Cyperaceae & Cyperus & sp. 1 & no & Grass & A & 7 & 22 \\
\hline Cyperaceae & Cyperus & sp. 2 & no & Grass & $A$ & 2 & 10 \\
\hline Euphorbiaceae & Euphorbia & tannensis & no & Forb & $A$ & 1 & 3 \\
\hline Euphorbiaceae & Euphorbia & boophthona & yes & Forb & $A$ & 2 & 4 \\
\hline Fabaceae & Acacia & sp. & $?$ & Shrub & $P$ & 2 & 6 \\
\hline Fabaceae & Swainsona & oroboides & no & Shrub & $P$ & 4 & 12 \\
\hline
\end{tabular}




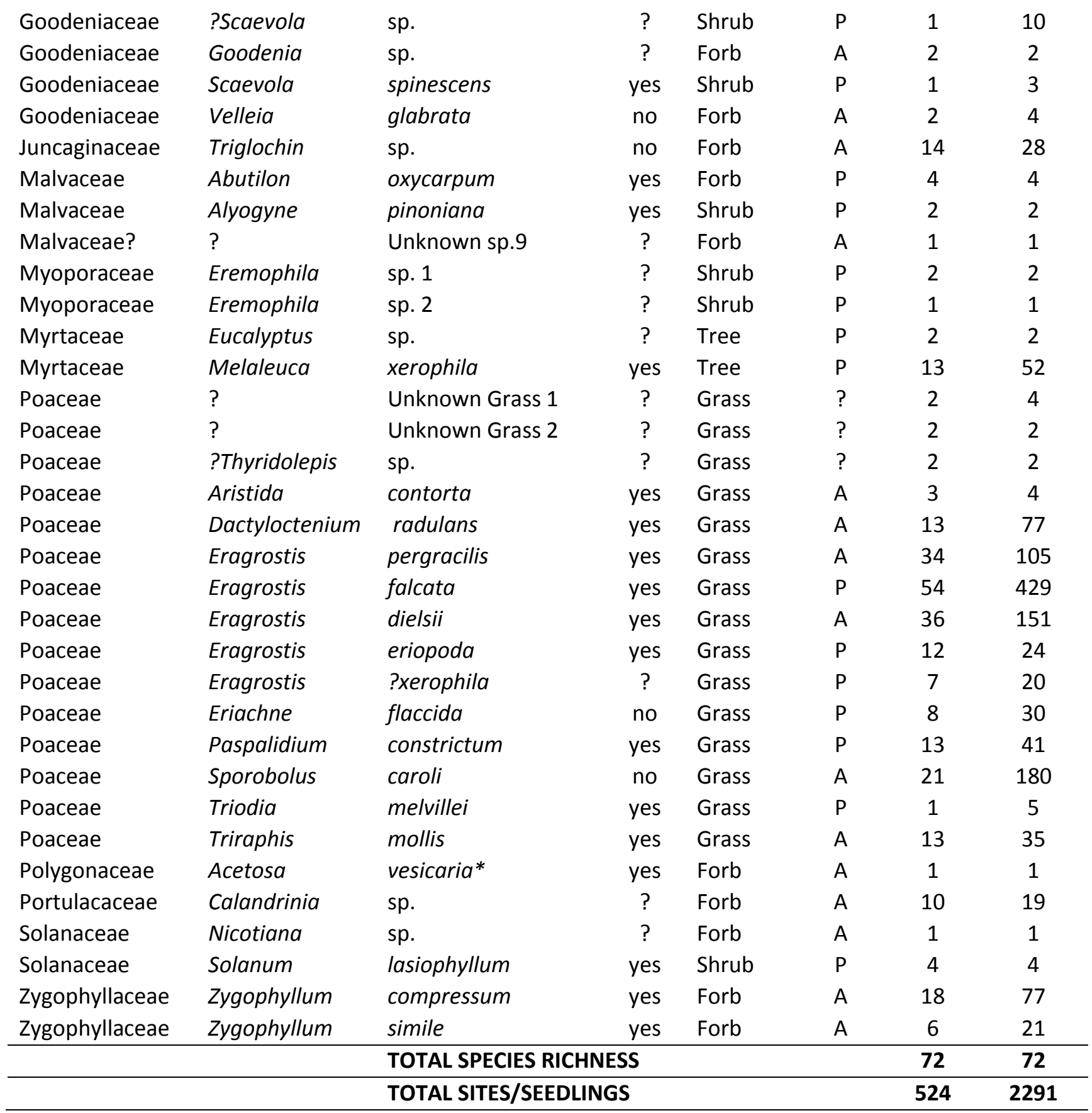

